\title{
PENGARUH MEKANISME CORPORATE GOVERNANCE DAN KARAKTERISTIK PERUSAHAAN TERHADAP PENGUNGKAPAN TANGGUNGJAWAB SOSIAL
}

\author{
Cahyaningsih \\ Institut Manajemen Telkom, Bandung, Indonesia \\ e-mail: ch_ningsih@yahoo.co.id \\ Venti Yustianti Martina \\ Institut Manajemen Telkom, Bandung, Indonesia \\ e-mail: ventiym@gmail.com
}

\begin{abstract}
This study aims to examine the influence of corporate governance mechanisms including an independent board and institutional ownership, and firm characteristics include leverage, priceto-book-value, as well as the size of the disclosure of corporate social responsibility. This study uses 52 companies listed on the Indonesia Stock Exchange during the years 2007-2008 as sample. The results show that simultaneous variables such as independent board, institutional holdings, leverage, price-to-book-value, and size have a significant effect on the disclosure of corporate social responsibility. With determination coefficient $\left(R^{2}\right)$ shows that inpendent variables can explain the dependent variable of $18.4 \%$, while the rest of $81.6 \%$ influenced by other factors. Based on partially test results show that the independent board and leverage have no significant negative effect and institutional ownership and size are not significant positive effect, while the price-tobook-value has significant positive effect on the disclosure of corporate social responsibility.
\end{abstract}

Keyword: corporate governance, firm characteristics, corporate social responsibility.

\begin{abstract}
Abstrak
Penelitian ini bertujuan untuk mengkaji pengaruh mekanisme corporate governance yang meliputi dewan komisaris independen dan kepemilikan institusional, serta karakteristik perusahaan yang meliputi leverage, price-to-book-value, serta size terhadap pengungkapan Tanggungjawab sosial (social responsibility). Sampel penelitian berjumlah 52 perusahaan yang terdaftar di Bursa Efek Indonesia selama tahun 2007-2008. Hasil pengujian empiris menunjukkan bahwa secara simultan variabel dewan komisaris independen, kepemilikan institusional, leverage, price-to-bookvalue, serta size berpengaruh signifikan terhadap pengungkapan Tanggungjawab sosial. Koefisien determinasi $\left(\mathrm{R}^{2}\right)$ menunjukkan bahwa variabel independen dapat menjelaskan variabel dependen sebesar 18,4\%, sedangkan sisanya sebesar $81,6 \%$ dipengaruhi oleh faktor lain. Berdasarkan pengujian secara parsial menunjukkan hasil bahwa dewan komisaris independen dan leverage berpengaruh negatif tidak signifikan serta kepemilikan institusional dan size berpengaruh positif tidak signifikan, sedangkan price-to-book-value berpengaruh positif signifikan terhadap pengungkapan Tanggungjawab sosial.
\end{abstract}

Kata kunci: corporate governance, karakteristik perusahaan, corporate social responsibility

\section{PENDAHULUAN}

\section{Latar Belakang Penelitian}

Di Indonesia, kesadaran akan perlunya menjaga lingkungan diatur oleh Undang-Undang Per- seroan Terbatas No.40 Pasal 74 tahun 2007, dimana perusahaan yang melakukan kegiatan usaha berkaitan dengan sumber daya alam wajib melakukan Tanggungjawab sosial dan lingkungan. Selain itu, berdasarkan Undang- 
Undang Penanaman Modal No. 25 tahun 2007 pasal 15 dan 34 disebutkan bahwa perusahaan yang tidak melaksanakan CSR akan dikenakan sanksi adminstratif berupa peringatan tertulis, pembatalan kegiatan usaha, pembekuan kegiatan usaha, dan yang terakhir adalah pencabutan izin kegiatan.

Saat ini sudah tidak relevan lagi apabila perusahaan dihadapkan dengan Tanggungjawab yang berpijak pada single bottom line yaitu nilai perusahaan ( corporate value) hanya dilihat dari kondisi keuangan (financial), sedangkan kondisi keuangan saja tidak cukup menjamin nilai perusahaan tumbuh secara berkelanjutan (sustainable). Tanggungjawab perusahaan harus berpijak pada triple bottom lines, yaitu nilai perusahaan (corporate value) dilihat dari keterkaitan antara aspek keuangan (financial), sosial (social) dan lingkungan (environmental). Sarana tersebut dikenal dengan nama laporan keberlanjutan (sustainability reporting). Triple bottom lines pertama kali diperkenalkan oleh John Elkington pada tahun 1997.

Pemikiran yang melandasi Corporate Social Responsibility (Tanggungjawab Sosial Perusahaan) yang sering dianggap inti dari etika bisnis adalah bahwa perusahaan tidak hanya mempunyai kewajiban-kewajiban ekonomi dan legal (artinya kepada pemegang saham atau shareholder) tetapi juga kewajibankewajiban terhadap pihak-pihak lain yang berkepentingan (stakeholder) yang jangkauannya melebihi kewajiban-kewajiban ekonomi dan legal. Tujuan perusahaan adalah menciptakan nilai bagi setiap stakeholder melalui penciptaan barang dan jasa. Tanggungjawab sosial dari perusahaan terjadi antara sebuah perusahaan dengan semua stakeholder, termasuk di dalamnya adalah primary stakeholder seperti pelanggan (customer), karyawan, komunitas, pemilik atau investor, pemerintah, serta secondary stakeholder seperti kreditur, supplier, media, bahkan juga kompetitor.

Jumlah perusahaan yang melakukan pengungkapan informasi Corporate Social Responsibility (CSR) dalam laporan tahunannya semakin bertambah. Demikian juga dengan jumlah dan jenis informasi CSR yang diungkapkan semakin meningkat. Banyak perusahaan semakin menyadari pentingnya menerapkan program CSR sebagai bagian dari strategi bisnisnya. Survei global yang dilaku- kan oleh The Economist Intelligence Unit menunjukkan bahwa $85 \%$ eksekutif senior dan investor dari berbagai organisasi menjadikan CSR sebagai pertimbangan utama dalam pengambilan keputusan (Warta Ekonomi, 2006).

Perusahaan mengungkapkan praktik Tanggungjawab sosial agar bentuk kontribusi yang telah dilakukan oleh perusahaan tersebut dapat diketahui oleh berbagai pihak yang berkepentingan. Pengungkapan Tanggungjawab sosial atau sering disebut corporate social reporting adalah proses pengkomunikasian efek-efek sosial dan lingkungan atas tindakan-tindakan ekonomi perusahaan pada kelompok-kelompok tertentu dalam masyarakat dan pada masyarakat secara keseluruhan.

Menurut Utama (2007) praktik dan pengungkapan CSR di Indonesia mulai berkembang seiring dengan semakin meningkatnya perhatian masyarakat global terhadap perkembangan perusahaan-perusahaan transnasional atau multinasional yang beroperasi di Indonesia. Keberadaan perusahaan di lingkungan masyarakat hampir pasti membawa dampak negatif, meskipun memiliki dampak positif berupa kesejahteraan dan pembangunan.

Beberapa kasus berskala nasional dan internasional seperti global warming, pencemaran, radiasi serta munculnya berbagai penyakit akibat infeksi bahan kimia adalah sederetan dampak negatif dari industrialisasi. Mencermati dampak industrialisasi tersebut, tidak adil apabila masyarakat harus menanggung beban sosial. Seharusnya perusahaan yang menanggung dampak indusrialisasi karena mereka adalah pihak yang menikmati dan memperoleh keuntungan besar dari industri. Sebagai contoh berbagai penyakit yang dirasakan oleh masyarakat Teluk Buyat di Sulawesi akibat limbah PT Newmont, banjir di Jakarta, dan korban Lapindo Brantas di Sidoarjo Jawa Timur adalah fakta kerugian sosial yang harus diderita oleh masyarakat akibat industrialisasi.

Terdapat berbagai alasan yang mendasari perusahaan melakukan CSR, antara lain: (1) keterlibatan sosial perusahaan terhadap masyarakat dalam memenuhi panggilan bahwa dirinya memiliki kepentingan terhadap masalah sosial di tengah masyarakat; (2) meningkatkan nama baik perusahaan, simpati masyarakat, karyawan, dan investor sehingga berharap feed back secara ekonomi; (3) menghindari campur 
tangan pemerintah dalam melindungi masyarakat; (4) sesuai dengan kehendak investor; (5) membantu program pemerintah seperti konservasi, pelestarian budaya, peningkatan pendidikan, lapangan kerja, dan lain-lain (Harahap, et al. dalam Hadi, 2011).

Praktik dan pengungkapan CSR merupakan konsekuensi logis dari implementasi konsep Good Corporate Governance (GCG), yang prinsipnya antara lain menyatakan bahwa perusahaan perlu memperhatikan kepentingan stakeholders-nya, sesuai dengan aturan yang ada dan menjalin kerjasama yang aktif dengan stakeholders demi kelangsungan hidup jangka panjang perusahaan (Utama, 2007). Pengaturan dan pengimplementasian GCG memerlukan komitmen dari seluruh jajaran organisasi dan dimulai dengan penetapan kebijakan dasar serta tata tertib yang harus dianut oleh top manajemen dan penerapan kode etik yang harus dipatuhi oleh semua pihak yang ada di dalamnya. Apabila sistem corporate governance yang terdiri atas struktur corporate governance (pemegang saham, dewan komisaris, dewan direksi, komite audit, sekretaris perusahaan, manajer dan karyawan, auditor) dilaksanakan dengan mekanisme yang baik dan dilandasi dengan prinsip corporate governance maka akan bermanfaat dalam mengatur dan mengendalikan perusahaan. Selain itu, Utama (2007) juga menyatakan bahwa mekanisme dan struktur governance di perusahaan dapat dijadikan sebagai pendukung terhadap praktik dan pengungkapan CSR di Indonesia.

Gagasan utama GCG atau tata kelola perusahaan yang baik adalah mewujudkan Tanggungjawab sosial (CSR). Pelaku CSR sebaiknya tidak memisahkan aktifitas CSR dengan GCG, karena keduanya merupakan satu continuum (kesatuan), dan bukan merupakan penyatuan dari beberapa bagian yang terpisahkan. Tanggungjawab sosial berorientasi kepada para stakeholders hal ini sejalan dengan salah satu prinsip utama GCG yaitu responsibility. Pengungkapan (disclosure) terhadap aspek social, ethical, environmental dan sustainability sekarang ini menjadi suatu cara bagi perusahaan untuk mengkomunikasikan bentuk akuntabilitasnya kepada para stakeholder.

Dewan Komisaris sebagai organ perusahaan merupakan mekanisme yang bertugas dan ber Tanggungjawab secara kolektif untuk melakukan pengawasan dan memberikan nasihat kepada pengelola perusahaan atau pihak manajemen serta memastikan bahwa perusahaan melaksanakan Good Corporate governance. Dewan Komisaris dapat terdiri dari Komisaris yang tidak berasal dari pihak terafiliasi dikenal sebagai Komisaris Independen dan Komisaris yang terafiliasi. Yang dimaksud dengan terafiliasi adalah pihak yang mempunyai hubungan bisnis dan kekeluargaan dengan pemegang saham pengendali, anggota Direksi dan Dewan Komisaris lain, serta dengan perusahaan itu sendiri. Mantan anggota Direksi dan Dewan Komisaris yang terafiliasi serta karyawan perusahaan, untuk jangka waktu tertentu termasuk dalam kategori terafiliasi (KNKG, 2006).

Jumlah Komisaris Independen harus dapat menjamin agar mekanisme pengawasan berjalan secara efektif dan sesuai dengan peraturan perundang-undangan. Penelitian Haniffa dan Coke (2002) menemukan bahwa apabila jumlah dewan komisaris independen semakin dominan, hal ini dapat memberikan power kepada Dewan Komisaris untuk menekan manajemen meningkatkan kualitas pengungkapan perusahaan.

Konsep corporate governance pada generasi pertama ditandai dengan kemunculan Jensen dan Meckling (1976) dengan teori keagenan (Agency Theory) dimana permasalahan agency muncul ketika pengelolaan suatu perusahaan diserahkan kepada manajer (agent) oleh pemilik/pemegang saham (principal). Oleh karena pemilik perusahaan memberikan kewenangan kepada manajer untuk mengelola perusahaan seperti mengelola dana dan mengambil keputusan untuk dan atas nama pemilik, maka mungkin saja pengelola tidak bertindak yang terbaik untuk kepentingan pemilik karena adanya perbedaan kepentingan (conflict interest). Struktur kepemilikan merupakan salah satu mekanisme GCG untuk mengendalikan masalah agensi pada perusahaan.

Mekanisme struktur kepemilikan antara lain yaitu struktur kepemilikan institusional. Menurut Tarjo (2008), kepemilikan institusional merupakan kepemilikan saham perusahaan yang dimiliki oleh instansi atau lembaga (perusahaan asuransi, bank, perseroan terbatas, perusahaan investasi dan kepemilikan institusi lainnya). Kepemilikan saham oleh institusi dianggap sebagai sophisticated investor karena mereka merupakan investor yang tidak mudah 
dibohongi manajer. Menurut Machmud dan Djakman (2008) dengan jumlah kepemilikan yang cukup signifikan dapat memonitor manajemen sehingga dapat mengurangi masalah keagenen. Semakin besar kepemilikan institusional diharapkan dapat bertindak sebagai pencegahan terhadap kecurangan yang dilakukan oleh manajemen. Hal ini berarti kepemilikan institusional dapat menjadi pendorong perusahaan untuk melakukan pengungkapan Tanggungjawab sosial.

Setiap perusahaan memiliki karakteristik yang berbeda-beda, karakteristik tersebut dapat dilihat dari risiko perusahaan, pertumbuhan perusahaan dan ukuran perusahaan. Karakteristik perusaaan tersebut dapat mempengaruhi luas atau sempitnya pengungkapan Tanggungjawab sosial atau CSR.

Beberapa penelitian yang dilakukan di Indonesia mengenai pengaruh karakteristik perusahaan terhadap pengungkapan Tanggungjawab sosial antara lain adalah Amalia (2005) menemukan bahwa rasio leverage dan luas pengungkapan sukarela berhubungan negatif dan secara statistik tidak signifikan. Penelitian Amalia (2005) menunjukkan bahwa secara statistik rasio PBV nilainya tidak signifikan mempengaruhi luas pengungkapan sukarela perusahaan. Ukuran perusahaan, profitabilitas, dan profil industri berkorelasi positif dengan pengungkapan informasi CSR (Sembiring, 2003; Sembiring, 2005; Haniffa dan Cooke, 2005; Sayekti, 2006; Anggraini, 2006). Berdasarkan hasil penelitian terdahulu yang tidak konsisten maka peneliti tertarik untuk meneliti ulang mengenai pengaruh karakteristik perusahaan terhadap pengungkapan Tanggungjawab sosial, yang dilihat dari risiko, peluang pertumbuhan perusahaan, serta ukuran perusahaan.

Penelitian terdahulu telah banyak menguji pengaruh volountary disclosure terhadap kinerja perusahaan atau nilai perusahaan, namun penelitian mengenai faktor-faktor yang mempengaruhi CSR belum secara luas diuji. Berdasarkan hal tersebut, maka tujuan penelitian ini adalah untuk melihat pengaruh Dewan Komisaris Independen, Kepemilikan Institusional, Leverage, Price-to-Book-Value (PBV), dan Size terhadap CSR. Penelitian ini untuk memperluas keberadaan hasil riset mengenai Pengungkapan Tanggungjawab Sosial yang telah dilakukan peneliti-peneliti sebelumnya terutama untuk melihat perkembangan pengungkapan informasi CSR pada periode penelitian yang terbaru.

Perbedaan penelitian ini terdapat pada beberapa hal. Pertama, penelitian ini menggunakan mekanisme GCG (meliputi Dewan Komisaris Independen dan Kepemilikan Institusional), serta karakteristik perusahaan (meliputi Leverage, Price-to-Book-Value (PBV), serta Size) sebagai variabel independen, karena hasil penelitian sebelumnya menyatakan bahwa ketiga variabel tersebut memiliki hubungan maupun pengaruh terhadap CSR, meskipun hasilnya tidak konsisten. Kedua, penelitian ini dilakukan dengan memperpanjang tahun pengamatan yaitu dua tahun (tahun 20072008) untuk mempertinggi daya uji empiris (Gujarati, 2000). Ketiga, sampel dalam penelitian ini yaitu semua perusahaan yang terdaftar di BEI selama tahun 2007-2008 kecuali sektor industri perbankkan dan keuangan karena sektor tersebut memiliki regulasi khusus dari pemerintah supaya efek CSR tidak bias.

Penelitian ini bertujuan untuk: (1) Mengetahui apakah Dewan Komisaris Independen berpengaruh signifikan terhadap Pengungkapan Tanggungjawab Sosial; (2) Mengetahui apakah Kepemilikan Institusional berpengaruh signifikan terhadap Pengungkapan Tanggungjawab Sosial; (3) Mengetahui apakah leverage berpengaruh signifikan terhadap Pengungkapan Tanggungjawab Sosial; (4) Mengetahui apakah PBV berpengaruh signifikan terhadap Pengungkapan Tanggungjawab Sosial; (5) Mengetahui apakah size berpengaruh signifikan terhadap Pengungkapan Tanggungjawab Sosial.

\section{KAJIAN PUSTAKA}

\section{Corporate Governance}

Good Corporate Governance atau yang biasa disingkat GCG berasal dari istilah corporate governance yang berarti tata kelola perusahaan. Menurut Sir Adrian Cadbury (Global Corporate Governance Forum - World Bank, 2000) menjelaskan Corporate Governance sebagai berikut: "Corporate Governance is concerned with holding the balance between economic and social goals and between individual and communal goals. The corporate governance framework is there to encourage the efficient use of resources and equally to require 
accountability for the stewardship of those resources. The aim is to align as nearly as possible the interests of individuals, corporations and society". Penjelasan ini menekankan bahwa Corporate Governance merupakan keseimbangan antara tujuan ekonomi dan tujuan sosial serta tujuan individu dan tujuan komunitas. Disamping itu juga menekankan akuntabilitas dalam pengelolaan segala sumber daya yang memperhatikan seluruh kepentingan, baik individu, perusahaan dan masyarakat.

Organization of Economic Cooperation and Development (OECD) mendefiniskan Corporate Governance sebagai berikut: "corporate governance is the system by which business corporations are directed and controlled. The Corporate Governance structure specifies the distribution of the right and responsibilities among different participants in the corporation, such as the board, managers, shareholders, and other stakeholders, and spells out the rules and procedures for making decisions on corporate affairs. By doing this, it also provides this structure through which the company objectives are set, and the means of attaining those objectives and monitoring performance" OECD melihat Corporate Governance sebagai suatu sistem dimana sebuah perusahaan atau entitas bisnis diarahkan dan diawasi. Sejalan dengan itu, maka struktur dari Corporate Governance menjelaskan distribusi hak-hak dan tanggungjawab dari masing-masing pihak yang terlibat dalam sebuah bisnis, yaitu antara lain Dewan Komisaris dan Direksi, Manajer, Pemegang saham, serta pihak-pihak lain yang terkait sebagai stakeholders. Selanjutnya, struktur dari Corporate Governance juga menjelaskan bagaimana aturan dan prosedur dalam pengambilan dan pemutusan kebijakan sehingga dengan melakukan itu semua maka tujuan perusahaan dan pemantauan kinerjanya dapat dipertangungjawabkan dan dilakukan dengan baik.

\section{Corporate Social Responsibility (CSR)}

Peraturan di Indonesia yang mengatur tentang pengungkapan adalah keputusan Badan Pengawas Pasar Modal dan Lembaga Keuangan (Bapepam-LK) No. Kep-38/PM/1996. Informasi yang diungkapkan dalam laporan tahunan perusahaan dapat dikelompokkan menjadi dua, yaitu pengungkapan wajib (mandatory disclo- sures) dan pengungkapan sukarela (voluntary disclosures). Pengungkapan wajib merupakan pengungkapan informasi yang diharuskan oleh peraturan yang berlaku, dalam hal ini adalah peraturan yang dikeluarkan oleh Bapepam-LK. Pengungkapan sukarela adalah pengungkapan informasi yang dilakukan secara sukarela oleh perusahaan tanpa diharuskan oleh peraturan yang berlaku atau pengungkapan melebihi yang diwajibkan. Pengungkapan CSR adalah contoh dari pengungkapan sukarela.

Corporate Social Responsibility (CSR) menurut The World Business Council for Sustainable Development (WBCSD) adalah suatu komitmen dari perusahaan untuk berperilaku etis (behavioral ethics) dan berkontribusi terhadap pembangunan ekonomi yang berkelanjutan (sustainable economic development), komitmen lainnya adalah meningkatkan kualitas hidup karyawan dan keluarganya, komunitas lokal serta masyarakat luas.

\section{Pengaruh Dewan Komisaris Independen terhadap Pengungkapan Tanggungjawab Sosial}

Jumlah anggota Dewan Komisaris harus disesuaikan dengan kompleksitas perusahaan dengan tetap memperhatikan efektivitas dalam pengambilan keputusan. Jumlah Komisaris Independen harus dapat menjamin agar mekanisme pengawasan berjalan secara efektif dan sesuai dengan peraturan perundangundangan.

Apabila jumlah Komisaris Independen semakin besar atau dominan, hal ini dapat memberikan power kepada Dewan Komisaris untuk menekan manajemen untuk meningkatkan kualitas pengungkapan perusahaan (Haniffa dan Cooke, 2002). Komisaris Independen diperlukan untuk meningkatkan independensi Dewan Komisaris terhadap kepentingan pemegang saham (mayoritas) dan benarbenar menempatkan kepentingan perusahaan di atas kepentingan lainnya (Muntoro, 2006). Dengan demikian, semakin besar komposisi Dewan Komisaris Independen, maka kemampuan Dewan Komisaris untuk mengambil keputusan dalam rangka melindungi seluruh pemangku kepentingan dan mengutamakan perusahaan semakin objektif. Dengan kata lain, semakin besar komposisi Komisaris Independen, maka Dewan Komisaris dapat bertindak 
semakin objektif dan mampu melindungi seluruh pemangku kepentingan. Dengan demikian hal ini mendorong pengungkapan CSR secara lebih luas. Berdasarkan uraian di atas, maka hipotesis yang diajukan dalam penelitian ini adalah sebagai berikut:

$\mathrm{H}_{1}$ : Dewan Komisaris Independen berpengaruh signifikan terhadap Pengungkapan Tanggungjawab Sosial

\section{Pengaruh Kepemilikan Institusional terhadap Pengungkapan Tanggungjawab Sosial}

Penelitian Trabelsi, et al. (2005) dan Ajinkya et al. (2005) dalam Matoussi dan Chakroun (2008), menemukan bahwa kepemilikan Institusional dapat meningkatkan kualitas dan kuantitas pengungkapan sukarela. Menurut Summa dan Ben Ali (2006) dalam Matoussi dan Chakroun (2008), Investor institusional memiliki power dan experience untuk ber Tanggungjawab dalam menerapkan prinsip corporate governance untuk melindungi hak dan kepentingan seluruh pemegang saham, sehingga mereka menuntut perusahaan untuk melakukan komunikasi secara transparan. Hal ini berarti, dengan kepemilikan institusional yang besar dapat mendorong meningkatkan luas pengungkapan CSR yang dilakukan oleh perusahaan. Berdasarkan asumsi tersebut, penelitian ini mengajukan hipotesis sebagai berikut:

$\mathrm{H}_{2}$ : Kepemilikan Institusional berpengaruh signifikan terhadap Pengungkapan Tanggungjawab Sosial

\section{Pengaruh Leverage terhadap Pengungkapan Tanggungjawab Sosial}

Meek dan Gray (1955) menyatakan semakin tinggi tingkat leverage perusahaan, semakin besar pula agency cost. Dengan kata lain untuk memenuhi kebutuhan kreditur jangka panjang perusahaan dituntut untuk melakukan pengungkapan yang lebih luas.

Jensen dan Meckling (1976) menyatakan bahwa perusahaan dengan leverage yang tinggi menanggung biaya pengawasan (monitoring cost) tinggi. Apabila menyediakan informasi secara lebih komprehensif akan membutuhkan biaya lebih tinggi, maka perusahaan dengan leverage lebih tinggi akan menyediakan informasi secara lebih komprehensif.
Suripto (1999) meneliti pengaruh karakteristik perusahaan terhadap luas pengungkapan sukarela dalam laporan tahunan. Karakteristik perusahaan dilambangkan dengan ukuran perusahaan (total asset), rasio leverage dan likuiditas sebagai variabel independent, sedangkan variabel dependent-nya adalah indeks pengungkapan. Hasil penelitian menunjukkan bahwa variabel-variabel tersebut secara bersama-sama mampu menjelaskan pengungkapan sukarela laporan keuangan tahunan. Akan tetapi secara individu, variabelvariabel tersebut tidak mampu menunjukkan pengaruh yang signifikan terhadap luas pengungkapan perusahaan.

Ainun dan Rakhman (2000) melakukan penelitian tentang analisis hubungan antara kelengkapan pengungkapan laporan keuangan dengan struktur modal dan tipe kepemilikan perusahaan. Hasil penelitian Ainun dan Rakhman (2000) menunjukkan leverage keuangan memiliki hubungan yang signifikan positif terhadap indeks kelengkapan pengungkapan.

Fitriani (2001) melakukan penelitian tentang signifikasi perbedaan tingkat kelengkapan pengungkapan wajib dan sukarela pada laporan keuangan. Fitriani (2001) menyimpulkan bahwa terdapat faktor yang mempengaruhi kelengkapan pengungkapan wajib adalah ukuran perusahaan, status perusahaan, jenis perusahaan, net profit margin. Tingkat leverage dan likuiditas tidak mempengaruhi indeks kelengkapan pengungkapan wajib dan sukarela.

Amalia (2005) menemukan bahwa rasio leverage dan luas pengungkapan sukarela berhubungan negatif dan secara statistik tidak signifikan. Penjelasan yang mungkin atas fenomena ini adalah bahwa perusahaan memiliki mekanisme lain untuk mengurangi biaya keagenan selain dari pengungkapan informasi dalam laporan tahunan.

Murwaningsari (2008) membuktikan bahwa terdapat pengaruh positif antara leverage dengan pengungkapan sukarela. Hasil penelitian Murwaningsari (2008) sejalan dengan Meek, et al., (1955), Jensen dan Meckling (1976), dan Ainun dan Rakhman (2000). Berdasarkan asumsi bahwa perusahaan dengan rasio hutang atas modal yang tinggi akan menyediakan informasi lebih banyak untuk memenuhi tuntutan debitur jangka panjang dibandingkan dengan perusahaan dengan 
rasio rendah, maka peneliti mengajukan hipotesis sebagai berikut:

$\mathrm{H}_{3}$ : Leverage berpengaruh signifikan terhadap Pengungkapan Tanggungjawab Sosial

\section{Pengaruh Price-to-Book-Value terhadap Pengungkapan Tanggungjawab Sosial}

Manajer yang merasa perusahaannnya dinilai terlalu rendah (undervalued), berusaha untuk mengungkapkan informasi privat yang dimilikinya sebanyak-banyaknya dengan tujuan mengurangi ketidakakuratan pasar dalam nilai perusahaannya. Manajer akan memberi sinyal ke pasar untuk mengindikasikan bahwa nilai perusahaannya sekarang terlalu rendah, dan tidak sesuai dengan nilai sebenarnya.

Proxy yang digunakan untuk perusahaan yang dinilai terlalu rendah adalah rasio nilai pasar terhadap nilai buku ekuitas. Rasio ini menunjukkan seberapa jauh suatu perusahaan mampu menciptakan nilai perusahaan relatif terhadap jumlah modal yang diinvestasikan, semakin tinggi rasio tersebut semakin berhasil perusahaan menciptakan nilai bagi pemegang saham.

Penelitian Amalia (2005) menunjukkan bahwa secara statistik rasio PBV nilainya tidak signifikan mempengaruhi luas pengungkapan sukarela perusahaan. Secara teori, perusahaan dengan rasio $\mathrm{PBV}$ yang rendah akan mengungkapkan lebih banyak informasi, karena rendahnya rasio PBV ini mengindikasikan kurangnya informasi relevan yang sampai ke pasar, sehingga manajer akan berusaha mengungkapkan informasi privat yang dimilikinya untuk meningkatkan nilai perusahaannya. Hasil penelitian Amalia (2005) justru menunjukkan hal yang sebaliknya, yaitu rasio PBV dan luas pengungkapan sukarela berhubungan positif (meskipun secara statistik tidak signifikan). Berdasarkan asumsi bahwa rasio PBV dan luas pengungkapan sukarela berhubungan positif, maka peneliti mengajukan hipotesis sebagai berikut:

$\mathrm{H}_{4}$ : PBV berpengaruh signifikan terhadap Pengungkapan Tanggungjawab Sosial

\section{Pengaruh Size terhadap Pengungkapan Tanggungjawab Sosial}

Pengungkapan informasi CSR itu sendiri merupakan suatu hal yang bersifat endogeneous (Core, 2001; Healy dan Palepu, 2001). Berbagai penelitian terdahulu mengenai faktorfaktor determinan yang mempengaruhi perusahaan dalam melakukan pengungkapan informasi CSR telah banyak dilakukan. Ukuran perusahaan, profitabilitas, dan profil industri berkorelasi positif dengan pengungkapan informasi CSR (Trotman dan Bradley, 1981; Kelly, 1981; McGuire et al. 1988; Roberts, 1992; Cowen et al. 1997; Utomo, 2000; Sembiring, 2003; Sembiring, 2005; Haniffa dan Cooke, 2005; Sayekti, 2006; Anggraini, 2006). Berdasarkan asumsi tersebut maka peneliti mengajukan hipotesis sebagai berikut:

$\mathrm{H}_{5}$ : Size berpengaruh signifikan terhadap Pengungkapan Tanggungjawab Sosial

\section{Kerangka Pemikiran}

\section{Variabel Dependen}

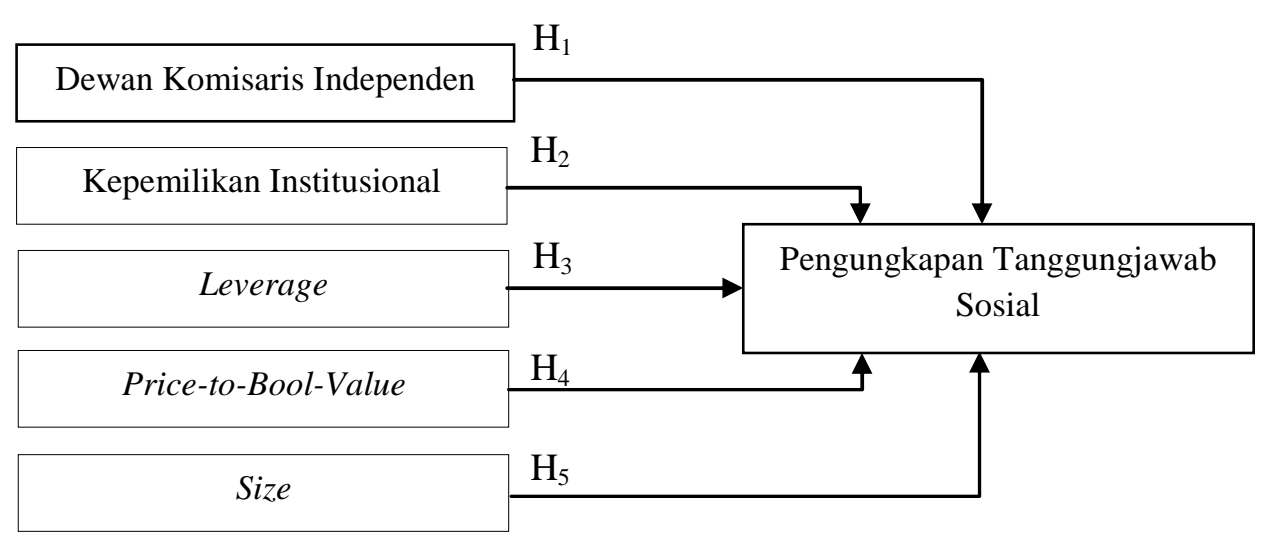

Gambar 1: Kerangka Pemikiran

Sumber: hasil olah data 
Secara garis besar penelitian ini terbagi menjadi dua tahap, tahap pertama yaitu mengetahui besarnya pengaruh simultan antar variabel dengan metode regresi linier berganda. Tahap kedua yaitu mengetahui besarnya pengaruh parsial antar variabel independen (Dewan Komisaris Independen, Kepemilikan Institusional, Leverage, PBV, serta Size) dengan variabel dependen (Pengungkapan CSR).

\section{METODE PENELITIAN}

\section{Desain Penelitian}

Jenis penelitian ini menggunakan hypothesis testing yang dapat menjelaskan mengenai beberapa hubungan dan pengaruh antarvariabel, memahami perbedaan antar kelompok dan independensi antarvariabel dalam suatu situasi. Penelitian ini dilakukan pada perusahaan yang terdaftar di BEI selama tahun 2007-2008. Penelitian ini menggunakan gabungan time horizon jenis cross sectional karena data yang digunakan diperoleh dari beberapa perusahaan untuk satu periode tertentu berupa data Dewan Komisaris Independen, Kepemilikan Institusional, leverage, PBV, Corporate Social Responsibility Index (CSRI) serta jenis time series karena data yang digunakan diperoleh dari beberapa perusahaan untuk beberapa periode tertentu yaitu selama tahun 2007-2008 (Hartono, 2003)

\section{Pemilihan Populasi dan Sampel}

Populasi penelitian meliputi seluruh perusahaan go public yang terdaftar di BEI. Periode penelitian selama dua tahun dengan alasan data yang dibutuhkan cukup tersedia serta untuk menyediakan data yang up to date. Sampel perusahaan dipilih berdasarkan purposive sampling yaitu suatu metode nonprobability sampling untuk penentuan sampel dari populasi yang memenuhi kriteria tertentu sesuai yang dikehendaki peneliti. Kriteria pemilihan sampel yaitu (1) sampel diambil dari populasi seluruh perusahaan dari tiga jenis sektor industri (primer, sekunder, tersier), dengan pengecualian terhadap sektor industri perbankkan dan keuangan karena sektor tersebut memiliki regulasi khusus dari pemerintah supaya hasil penelitian tidak bias; (2) saham perusahaan aktif diperdagangkan, mengacu S.E PT BEJ
No.03/BEJ.II.I/I/1994 yaitu frekuensi perdagangan lebih dari 75 kali dalam 3 bulan; (3) menerbitkan audited annual report selama tahun 2007-2008; (4) melakukan pengungkapan sukarela berupa Tanggungjawab sosial, serta (5) memiliki data lengkap yang digunakan sebagai variabel dalam penelitian ini dan secara konsisten dilaporkan di JSX Monthly Statistics 2007-2008.

Tabel 1: Proses Pemilihan Sampel

\begin{tabular}{lc}
\hline \multicolumn{1}{c}{ Keterangan } & $\begin{array}{c}\text { Jumlah } \\
\text { Sampel }\end{array}$ \\
\hline $\begin{array}{l}\text { Perusahaan yang terdaftar di } \\
\text { Bursa Efek Indonesia }\end{array}$ & 391 \\
$\begin{array}{l}\text { Perusahaan dalam sektor industri } \\
\text { Perbankkan dan Keuangan }\end{array}$ & 69 \\
$\begin{array}{l}\text { Perusahaan dengan saham pasif, } \\
\text { tidak terdapat CSR, serta data } \\
\text { tidak lengkap }\end{array}$ & 270 \\
Jumlah sampel perusahaan & 52 \\
\hline Sumber: hasil olah data &
\end{tabular}

Perusahaan yang menjadi sampel penelitian yaitu perusahaan yang terdaftar di BEI, melakukan Pengungkapan Tanggungjawab Sosial, memiliki perdagangan saham yang aktif, serta data laporan keuangan lengkap yaitu berjumlah 52 perusahaan.

\section{Jenis dan Teknik Pengumpulan Data}

Jenis data dalam penelitian ini adalah data sekunder, berasal dari data yang dipublikasikan dalam data statistik atau jurnal lainnya dan informasi yang tersedia dari berbagai sumber yang telah dipublikasikan ataupun tidak dipublikasikan baik di dalam atau di luar organisasi, yang semuanya mungkin sangat berguna bagi peneliti. Data tersebut antara lain (1) data indek CSR diperoleh dari laporan tahunan untuk tahun 2007 dan 2008 dari perusahaan yang terdaftar di BEI; (2) data harga saham harian untuk menghitung return saham dan Indeks Harga Saham Gabungan (IHSG) harian untuk menghitung return pasar diperoleh dari situs BEI (www.jsx.co.id) dan situs www.yahoofinance.com; serta (3) data perusahaan emiten yang dikeluarkan BEI diperoleh dari JSX Monthly Statistics 2007-2008 dan JSX Fact Book 2007-2008. 


\section{Definisi Operasional dan Pengukuran Variabel}

Dalam penelitian ini terdapat satu variabel dependen yaitu Pengungkapan Tanggungjawab
Sosial serta terdapat lima variabel independen yaitu Dewan Komisaris Independen, Kepemilikan Institusional, Leverage, Price-toBook-Value, serta Size.

Tabel 2: Operasionalisasi Variabel

\begin{tabular}{|c|c|c|c|}
\hline Variabel & Konsep Variabel / Dimensi & Indikator & Skala \\
\hline $\begin{array}{l}\text { Pengungkapan } \\
\text { Tanggungjawab } \\
\text { Sosial } \\
\text { (Y) }\end{array}$ & $\begin{array}{l}\text { komitmen bisnis untuk } \\
\text { memberikan kontribusi bagi } \\
\text { pembangunan ekonomi } \\
\text { berkelanjutan, melalui kerja } \\
\text { sama dengan para karyawan } \\
\text { serta perwakilan mereka, } \\
\text { keluarga mereka, komunitas } \\
\text { setempat maupun masyarakat } \\
\text { umum untuk meningkatkan } \\
\text { kualitas kehidupan dengan cara } \\
\text { yang bermanfaat baik bagi } \\
\text { bisnis sendiri maupun untuk } \\
\text { pembangunan. }\end{array}$ & $\begin{array}{l}\text { Pengukuran luas } \\
\text { pengungkapan informasi } \\
\text { CSR dalam annual report } \\
\text { perusahaan menggunakan } \\
\text { CSR disclosures indeks } \\
\text { (CSRI) (Sayekti dan } \\
\text { Wondabio, 2007) }\end{array}$ & Rasio \\
\hline $\begin{array}{l}\text { Dewan Komisaris } \\
\text { Independen (proksi } \\
\text { mekanisme GCG) } \\
\left(\mathrm{X}_{1}\right)\end{array}$ & $\begin{array}{l}\text { Jumlah Dewan komisaris yang } \\
\text { tidak berasal dari pihak } \\
\text { terafiliasi. }\end{array}$ & $\begin{array}{l}\text { Proporsi Dewan Komisaris } \\
\text { Independen terhadap jumlah } \\
\text { keseluruhan Dewan } \\
\text { Komisaris }\end{array}$ & Rasio \\
\hline $\begin{array}{l}\text { Kepemilikan } \\
\text { Institusional (proksi } \\
\text { mekanisme GCG) } \\
\left(\mathrm{X}_{2}\right)\end{array}$ & $\begin{array}{l}\text { Jumlah kepemilikan saham } \\
\text { perusahaan yang dimiliki oleh } \\
\text { instansi atau lembaga. }\end{array}$ & $\begin{array}{l}\text { Perbandingan antara jumlah } \\
\text { kepemilikan institusional } \\
\text { dengan total saham yang } \\
\text { beredar }\end{array}$ & Rasio \\
\hline $\begin{array}{l}\text { Leverage } \\
\text { (proksi risiko) }\left(\mathrm{X}_{3}\right)\end{array}$ & $\begin{array}{l}\text { besarnya hutang menunjukkan } \\
\text { kualitas perusahaan serta } \\
\text { prospek yang kurang baik pada } \\
\text { masa mendatang }\end{array}$ & $\begin{array}{l}\text { Perbandingan antara total } \\
\text { hutang dengan total modal }\end{array}$ & Rasio \\
\hline $\begin{array}{l}\text { Price-to-Book-Value } \\
\text { (proksi kesempatan } \\
\text { pertumbuhan) }\left(\mathrm{X}_{4}\right)\end{array}$ & $\begin{array}{l}\text { Rasio ini menunjukkan } \\
\text { seberap jauh suatu perusahaan } \\
\text { mampu menciptakan nilai } \\
\text { perusahaan relatif terhadap } \\
\text { jumlah modal yang } \\
\text { diinvestasikan, semakin tinggi } \\
\text { rasio tersebut semakin berhasil } \\
\text { perusahaan menciptakan nilai } \\
\text { bagi pemegang saham. }\end{array}$ & $\begin{array}{l}\text { Perbandingan antara harga } \\
\text { saham dan nilai buku } \\
\text { ekuitas dari suatu } \\
\text { perusahaan }\end{array}$ & Rasio \\
\hline $\begin{array}{l}\text { Size } \\
\text { (proksi } \\
\text { keinformatifan harga } \\
\text { saham) }\left(\mathrm{X}_{5}\right)\end{array}$ & $\begin{array}{l}\text { Ukuran perusahaan (siz£ } \\
\text { merupakan proksi yang baik } \\
\text { untuk tingkat publisitas } \\
\text { informasi yang tersedia dari } \\
\text { suatu perusahaan. }\end{array}$ & $\begin{array}{l}\text { Logaritma Natural (Ln) } \\
\text { Total Aktiva }\end{array}$ & interval \\
\hline
\end{tabular}




\section{Metode Analisis Data}

Pengolahan data menggunakan signifikansi $\alpha$ $=5 \%$ dan alat analisis SPSS 12.0 for windows. Sebelum pengujian hipotesis, terlebih dahulu dilakukan tahapan sebagai berikut:

\section{Indeks Pengungkapan Tanggungjawab Sosial}

Instrumen pengukuran CSR yang akan digunakan dalam penelitian ini mengacu pada instrumen yang digunakan oleh Sembiring (2005), yang mengelompokkan informasi CSR ke dalam kategori berupa Lingkungan, Energi, Tenaga Kerja, Produk, Keterlibatan Masyarakat, dan Umum. Total items CSR berkisar antara 63 sampai dengan 78, tergantung dari jenis industri perusahaan.

Pendekatan untuk menghitung CSR pada dasarnya menggunakan pendekatan dikotomi yaitu setiap item CSR dalam instrumen penelitian diberi nilai 1 jika diungkapkan, dan nilai 0 jika tidak diungkapkan (Haniffa dan Cooke, 2005). Selanjutnya, skor dari setiap item dijumlahkan untuk memperoleh keseluruhan skor untuk setiap perusahaan. Rumus perhitungan CSR adalah sebagai berikut (Haniffa dan Cooke, 2005):

$$
\mathrm{CSR}_{\text {it }}=\Sigma \mathrm{X}_{\mathrm{i}} / \mathrm{n}_{\mathrm{i}}
$$

Dalam hal ini:

$\mathrm{CSR}_{\mathrm{it}}=$ Corporate Social Responsibility Index perusahaan i pada periode $\mathrm{t}$

$\mathrm{n} \quad=$ jumlah item CSR yaitü8 item

$\Sigma \mathrm{X}_{\mathrm{i}}=$ jumlah pengungkapan CSR dalam annual report audited

Dengan demikian, $0 \leq \mathrm{CSR}_{\text {it }} \leq 1$

\section{Asumsi Model Regresi Linier Normal Klasik}

Dalam penelitian ini digunakan metode OLS (Ordinary Least Square), maka perlu dilakukan uji terhadap model regresi apakah berdistribusi normal dan apakah terjadi penyimpangan terhadap asumsi model klasik. Model regresi akan menghasilkan estimator tidak bias yang baik (BLUE) jika memenuhi asumsi klasik, yaitu bebas multikolinieritas, bebas autokorelasi, dan bebas heteroskedastisitas. Jika asumsi klasik tidak dipenuhi maka variabel yang menjelaskan menjadi tidak efisien (Gujarati, 2000).

\section{Uji Normalitas Data}

Uji normalitas data menggunakan One-Sample Kolmogorov Smirnov Test (Santoso, 2000).
Data yang berdistribusi normal akan ditandai dengan Asymp. Sig (2-tailed) > 0,05. Uji normalitas dilakukan guna menguji apakah variabel dependen dan variabel independen mempunyai distribusi normal atau tidak. Model regresi yang baik memiliki distribusi data normal atau mendekati normal.

\section{Uji Multikolinieritas}

Santoso (2000) mengatakan bahwa apabila pada model regresi ditemukan adanya korelasi antara variabel independen maka terdapat masalah Multikolinieritas. Model regresi yang baik seharusnya tidak terjadi korelasi di antara variabel independen. Deteksi multikolinieritas menggunakan besaran VIF (Variance Inflation Factor) dan Tolerance (nilai toleransi).

Catatan: Tolerance $=1 / \mathrm{VIF}$ atau bisa juga VIF $=1 /$ Tolerance

\section{Uji Autokorelasi}

Santoso (2000) mengatakan apabila suatu model regresi linier ada korelasi antara kesalahan pengganggu pada periode $t$ dengan kesalahan pengganggu pada periode $\mathrm{t}-1$ (sebelumnya), maka terjadi autokorelasi. Model regresi yang baik adalah bebas autokorelasi. Deteksi autokorelasi melalui Durbin Watson Test dengan menentukan nilai Durbin Watson (DW), kemudian dari jumlah observasi (n) dan jumlah variabel independen $(\mathrm{k})$ ditentukan nilai batas atas $\left(\mathrm{d}_{\mathrm{U}}\right)$ dan batas bawah $\left(\mathrm{d}_{\mathrm{L}}\right)$.

\section{Uji Heteroskedastisitas}

Santoso (2000) mengatakan apabila suatu model regresi, terdapat kesamaan varian dari residual dari satu pengamatan ke pengamatan yang lain, maka disebut homoskedastisitas, dan jika varian berbeda disebut heteroskedastisitas. Deteksi adanya heteroskedastisitas dengan melihat ada tidaknya pola tertentu pada grafik, dimana sumbu $\mathrm{X}$ adalah $\mathrm{Y}$ yang telah diprediksi, dan sumbu $\mathrm{X}$ adalah residual (Y prediksi - Y sesungguhnya) yang telah di-studentized.

\section{Analisis Data dengan Metode Regresi Linier Berganda}

Pengujian pengaruh antara Dewan Komisaris Independen, Kepemilikan Institusional, Leverage, PBV, serta Size (sebagai variabel independen) terhadap CSR (sebagai variabel dependen). Pengujian $\mathrm{H}_{1}, \mathrm{H}_{2}, \mathrm{H}_{3}, \mathrm{H}_{4}$ serta $\mathrm{H}_{5}$ menggunakan uji t dengan signifikansi $\alpha=5 \%$ 
dan alat analisis SPSS 12.0 for windows. Penyebaran ke persamaan regresi linier berganda:

$$
\begin{aligned}
\text { CSR }= & \beta_{0}+\beta_{1} \text { DEKOMIND }+\beta_{2} \text { KEPINS }+ \\
& \beta_{3} \text { LEV }+\beta_{4} \text { PBV }+\beta_{5} \text { SIZE }+\varepsilon_{\text {it }}
\end{aligned}
$$

Dalam hal ini:

$\mathrm{CSR}_{\mathrm{it}}=\mathrm{CSR}$ perusahaan $\mathrm{i}$ pada periode $\mathrm{t}$

DEKOMIND $_{\mathrm{it}}=$ Dewan Komisaris Independen perusahaan i pada periode $t$

KEPINS $_{\text {it }}=$ Kepemilikan Institusional perusahaan i pada periode $\mathrm{t}$

$\mathrm{PBV}_{\mathrm{it}} \quad=$ Price-to-Book-Value perusahaan i pada periode $\mathrm{t}$

$\mathrm{LEV}_{\mathrm{it}}=$ Leverage perusahaan $\mathrm{i}$ pada periode $\mathrm{t}$

$\mathrm{SIZE}_{\mathrm{it}}=$ ukuran perusahaan i pada periode $\mathrm{t}$

$\varepsilon_{\mathrm{it}} \quad=$ komponen error perusahaan $\mathrm{i}$ pada periode $\mathrm{t}$

\section{Pengujian Hipotesis}

Hipotesis yang diajukan (secara parsial):

$\mathrm{H}_{0}$ : variabel independen secara parsial berpengaruh tidak signifikan terhadap variabel dependen.

$\mathrm{H}_{1}$ : variabel independen secara parsial berpengaruh signifikan terhadap variabel dependen.

Hipotesis yang diajukan (secara simultan):

$\mathrm{H}_{0}$ : variabel independen secara simultan berpengaruh tidak signifikan terhadap variabel dependen.

$\mathrm{H}_{1}$ : variabel independen secara simultan berpengaruh signifikan terhadap variabel dependen.

Kriteria Pengambilan Keputusan

Jika nilai $\rho$-value pada kolom sig. > level of significant $(\alpha)$, maka $\mathrm{H}_{0}$ diterima

Jika nilai $\rho$-value pada kolom sig. < level of significant $(\alpha)$, maka $\mathrm{H}_{1}$ diterima

\section{HASIL PENELITIAN}

\section{Hasil Pengujian Asumsi Model Regresi Linier Normal Klasik}

Model regresi akan menghasilkan estimator tidak bias yang baik (BLUE) jika memenuhi asumsi klasik, yaitu data berdistribusi normal, bebas multikolinieritas, bebas autokorelasi, dan bebas heteroskedastisitas. Berdasarkan hasil pengujian asumsi model regresi linier normal klasik bahwa data penelitian ini telah berdistribusi normal, bebas multikolinieritas, bebas autokorelasi, dan bebas heteroskedastisitas.

\section{Hasil Pengujian Pengaruh Dewan Komisaris Independen, Kepemilikan Institusional, Leverage, PBV, serta Size terhadap Pengungkapan CSR (Pengujian $\mathrm{H}_{1}, \mathrm{H}_{2}, \mathrm{H}_{3}$, $\mathbf{H}_{4}, \mathbf{H}_{5}$ )}

Tabel 3 menunjukkan bahwa Dewan Komisaris Independen berpengaruh negatif tidak signifikan terhadap Pengungkapan Tanggungjawab Sosial. Hasil ini konsisten dengan penelitian Said et.al. (2009) yang menunjukkan bahwa proporsi dewan komisaris independen tidak dapat berpengaruh terhadap luas pengungkapan CSR perusahaa. Penjelasan yang mungkin atas fenomena ini adalah terdapat indikasi adanya kemungkinkan pemilihan dan pengangkatan Komisaris Independen yang kurang efektif. Hal ini merupakan isu atau hal yang penting, bahwa banyak anggota Dewan Komisaris Independen tidak dapat menunjukkan independensinya atau sebenarnya tidak independen (not truly independent), sehingga fungsi pengawasan tidak dapat berjalan dengan baik. Dengan demikian, keberadaan atau proporsi Komisaris Independen belum dapat mempengaruhi luas pengungkapan CSR.

Tabel 3: Hasil Pengujian Regresi CSR

\begin{tabular}{lrrrcrl}
\hline \multicolumn{1}{c}{ Variabel } & Koefisien & \multicolumn{1}{c}{$\mathrm{t}$} & $\mathrm{F}$ & \multicolumn{1}{c}{ Sig. } & $\mathrm{R}^{2}$ & SEE \\
\hline Konstanta & -2.659 & -9.446 & & 0.000 & & \\
DEKOMIND & -0.396 & -1.396 & & 0.166 & & \\
KEPINS & 0.242 & 1.447 & & 0.151 & & \\
LEV & -0.049 & -1.657 & & 0.101 & & \\
PBV & 0.102 & 2.599 & & 0.011 & & \\
SIZE & 0.050 & 1.748 & & 0.084 & & \\
Model & & & 4.412 & 0,001 & 0,184 & 0,350 \\
\hline
\end{tabular}

Sumber: hasil olah data 
Tabel selanjutnya menggambarkan persamaan regresi:

$$
\begin{aligned}
\text { CSR }= & -2,659-0,396 \text { DEKOMIND }+ \\
& 0,242 \text { KEPINS }-0,049 \mathrm{LEV}+0,102 \\
& \text { PBV }+0,050 \text { SIZE } \\
\text { CSR }= & -2,659 ; \text { apabila variabel lain bernilai } \\
& \text { nol }(0) \\
\text { CSR }= & -0,396 \text { DEKOMIND; } r \text { artinya } \\
& \text { DEKOMIND berpengaruh negatif } \\
& \text { sebesar }-0,396 \text { terhadap Pengungkapan } \\
& \text { Tanggungjawab sosial, apabila variabel } \\
& \text { lain bernilai nol }(0)
\end{aligned}
$$

CSR $=0,242 \mathrm{KEPINS} ;$ artinya KEPINS berpengaruh positif sebesar 0,242 terhadap Pengungkapan Tanggungjawab sosial, apabila variabel lain bernilai nol (0)

CSR = -0,049LEV; artinya LEV berpengaruh negatif sebesar $-0,049$ terhadap Pengungkapan Tanggungjawab sosial, apabila variabel lain bernilai nol (0)

$\mathrm{CSR}=0,102 \mathrm{PBV}$; artinya PBV berpengaruh positif sebesar 0,102 terhadap Pengungkapan Tanggungjawab sosial, apabila variabel lain bernilai nol $(0)$

$\mathrm{CSR}=0,050$ SIZE; artinya SIZE berpengaruh positif sebesar 0,050 terhadap Pengungkapan Tanggungjawab sosial, apabila variabel lain bernilai nol (0)

Tabel 3 menunjukkan bahwa Kepemilikan Institusional berpengaruh positif tidak signifikan terhadap Pengungkapan Tanggungjawab Sosial. Hasil ini sesuai dengan penelitian Matoussi dan Chakroun (2008). Penjelasan yang mungkin atas fenomena ini adalah terdapat indikasi bahwa Investor institusional memiliki power dan experience untuk ber Tanggungjawab dalam menerapkan prinsip corporate governance untuk melindungi hak dan kepentingan seluruh pemegang saham, sehingga mereka menuntut manajemen untuk melakukan komunikasi secara transparan dengan meningkatkan luas pengungkapan CSR. Namun apabila investor institusional kurang peduli dengan pelaksanaan Tanggungjawab sosial perusahaan, maka mereka kurang menuntut manajemen untuk meningkatkan luas pengungkapan CSR.

Tabel 3 menunjukkan bahwa leverage berpengaruh negatif tidak signifikan terhadap Pengungkapan Tanggungjawab Sosial. Penjelasan yang mungkin atas fenomena ini adalah terdapat indikasi bahwa perusahaan dengan risiko besar menyembunyikan informasi yang seharusnya diungkapkan kepada para stakeholder sehingga semakin besar risiko perusahaan maka semakin sedikit pengungkapan informasi CSR yang dilakukan, meskipun terdapat indikasi bahwa perusahaan dengan risiko kecil melakukan hal yang sama. Perusahaan tersebut belum bisa memenuhi kebutuhan kreditur jangka panjang untuk melakukan pengungkapan yang lebih komprehensif. Hasil penelitian ini konsisten dengan penelitian Amalia (2005). Hasil penelitian ini berbeda dengan penelitian Ainun dan Rakhman (2000) .

Tabel 3 menunjukkan bahwa Price-toBook-Value berpengaruh positif signifikan terhadap Pengungkapan Tanggungjawab Sosial. Penjelasan yang mungkin atas fenomena ini adalah terdapat indikasi bahwa Manajer dari perusahaan tumbuh yang merasa perusahaannya dinilai terlalu rendah (undervalued), berusaha untuk mengungkapkan informasi privat yang dimiliki sebanyak-banyaknya dengan tujuan mengurangi ketidakakuratan pasar dalam nilai perusahaannya. Manajer akan memberi sinyal ke pasar untuk mengindikasikan bahwa nilai perusahaannya sekarang terlalu rendah, dan tidak sesuai dengan nilai sebenarnya. Hasil penelitian ini konsisten dengan penelitian Amalia (2005).

Tabel 3 menunjukkan bahwa Size berpengaruh positif tidak signifikan terhadap Pengungkapan Tanggungjawab Sosial. Penjelasan yang mungkin atas fenomena ini adalah terdapat indikasi bahwa perusahaan besar maupun kecil memiliki keleluasaan dalam melakukan pengungkapan sukarela dalam laporan tahunan sehingga menimbulkan adanya keragaman atau variasi luas pengungkapan sukarela antar perusahaan.

Tabel 3 menunjukkan bahwa variabel independen yaitu Dewan Komisaris Independen, Kepemilikan Institusional, Leverage, Price-to-Book-Value, serta Size secara simultan berpengaruh signifikan terhadap Pengungkapan Tanggungjawab Sosial. Variabel independen dapat menjelaskan variabel dependen yaitu sebesar 18,4\%, sedangkan sisanya sebesar $81,6 \%$ dipengaruhi oleh faktor lain. Nilai Standar Error of Estimate (SEE) sebesar 0,350 menunjukkan bahwa semakin kecil nilai SEE berarti model regresi semakin baik. 


\section{PENUTUP}

Berdasarkan hasil pengujian hipotesis yang telah diuraikan pada bab sebelumnya, maka peneliti dapat mengambil beberapa kesimpulan yaitu (1) bukti empiris menunjukkan hasil bahwa Dewan Komisaris Independen berpengaruh negatif tidak signifikan terhadap Pengungkapan Tanggungjawab Sosial, hasil ini konsisten dengan penelitian Said, et.al (2009); (2) bukti empiris menunjukkan hasil bahwa Kepemilikan Institusional berpengaruh positif tidak signifikan terhadap Pengungkapan Tanggungjawab Sosial, hasil ini sesuai dengan penelitian Matoussi dan Chakroun (2008); (3) bukti empiris menunjukkan hasil bahwa Leverage berpengaruh negatif tidak signifikan terhadap Pengungkapan Tanggungjawab Sosial, hasil penelitian ini konsisten dengan penelitian Amalia (2005); (4) bukti empiris menunjukkan hasil bahwa Price-to-Book-Value berpengaruh positif signifikan terhadap Pengungkapan Tanggungjawab Sosial, hasil penelitian ini konsisten dengan hasil penelitian yang dilakukan oleh Amalia (2005); (5) bukti empiris menunjukkan hasil bahwa Size berpengaruh positif tidak signifikan terhadap Pengungkapan Tanggungjawab Sosial, perusahaan besar maupun kecil memiliki keleluasaan dalam melakukan pengungkapan sukarela dalam laporan tahunan; (6) hasil pengujian empiris menunjukkan bahwa secara simultan variabel Dewan Komisaris Independen, Kepemilikan Institusional, Leverage, Price-to-Book-Value, serta Size secara simultan berpengaruh signifikan terhadap Pengungkapan Tanggungjawab Sosial, sehingga variabel independen dapat menjelaskan variabel dependen sebesar $18,4 \%$, sedangkan sisanya sebesar 81,6\% dipengaruhi oleh faktor lain.

Penelitian ini diharapkan dapat memberikan manfaat kepada beberapa pihak yaitu (1) investor dan investor potensial yaitu bahwa dari hasil penelitian ini diharapkan dapat memberikan wacana baru dalam mempertimbangkan aspek-aspek yang perlu diperhitungkan dalam investasi yang tidak terpaku pada ukuran-ukuran moneter; (2) perusahaan berkaitan dengan Pengungkapan Tanggungjawab Sosial yang telah mereka lakukan selama ini, hasil penelitian ini selanjutnya dapat menjadikan perusahaan lebih peduli terhadap Pengungkapan Tanggungjawab Sosial di masa mendatang, dengan alasan bahwa pengungkapan CSR tersebut tidak hanya dilihat sebagai cost tetapi merupakan sesuatu yang penting dan bermanfaat karena dapat meningkatkan nilai perusahaan, competitive advantage, serta corporate sustainability; (3) Badan Penyusun Standar Akuntansi dan Badan Otoritas Pasar Modal mengenai relevansi dari Pengungkapan Tanggungjawab Sosial dalam laporan tahunan perusahaan, hasil penelitian ini selanjutnya dapat menjadi masukan dalam mempertimbangkan apakah informasi CSR sudah waktunya diungkapkan dalam laporan tahunan perusahaan atau tidak. Hasil penelitian ini selanjutnya diharapkan dapat membantu untuk mengembangkan, mengubah, menambah dan menjelaskan standar akuntansi yang berlaku untuk menciptakan pasar modal yang efisien; (4) Pemerintah mengenai gambaran sampai sejauh mana Pengungkapan Tanggungjawab Sosial telah dilakukan perusahaan. Pemerintah diharapkan dapat mempertimbangkan, merumuskan, dan menetapkan suatu standar pelaporan CSR yang sesuai dengan kondisi Indonesia. Pemerintah juga diharapkan dapat menindaklanjuti pengesahan UU Perseroan Terbatas, dengan mewajibkan semua perusahaan untuk melaksanakan CSR; (5) masyarakat yaitu bahwa dari hasil penelitian ini diharapkan dapat memberikan stimulus secara proaktif sebagai pongontrol atas perilaku perusahaan dan meningkatkan kesadaran masyarakat akan hak-hak yang harus diperoleh; (6) akademisi yaitu bahwa dari hasil penelitian ini diharapkan dapat memperluas keberadaan hasil riset mengenai Pengungkapan Tanggungjawab Sosial dan GCG yang telah dilakukan peneliti-peneliti sebelumnya; (7) penelitian selanjutnya yaitu bahwa dari hasil penelitian ini diharapkan dapat menjadi tambahan literature untuk penelitian berikutnya. Penelitian berikutnya perlu mempertimbangkan perbaikan dalam penilaian luas ungkapan sukarela dengan memberi bobot pada tingkat kerincian suatu item informasi yang diungkapkan oleh perusahaan sehingga indeks ungkapan menjadi lebih teliti.

Penelitian ini memiliki beberapa kelemahan antara lain (1) penggunaan purposive sampling sehingga hasil peneltian ini tidak dapat digunakan sebagai dasar generalisasi; (2) penggunaan checklist dapat menyebabkan perbedaan dalam penilaian pengungkapan CSR. 


\section{DAFTAR PUSTAKA}

Ainun dan F. Rakhman. 2000. Analisis Hubungan antara Kelengkapan Pengungkapan Laporan Keuangan dengan Struktur Modal dan Tipe Kepemilikan Perusahaan. Jurnal Ekonomi dan Bisnis Indonesia. 115 (1). 70-82.

Anggraini, F. 2006. Pengungkapan Informasi Sosial dan Faktor-Faktor yang Mempengaruhi Pengungkapan Informasi Sosial dalam Laporan Keuangan Tahunan (Studi Empiris pada Perusahaan-Perusahaan yang terdaftar di Bursa Efek Jakarta). Simposium Nasional Akuntansi 9.

Amalia, D. 2005. Faktor-Faktor yang Mempengaruhi Luas Pengungkapan Sukarela (Voluntary Disclosure) pada Laporan Tahunan Perusahaan yang Tercatat di Bursa Efek Jakarta. Jurnal Akuntansi Pemerintah.

Arif, IY. 2006. Pengaruh Struktur Kepemilikan dan Mekanisme Corporate Governance Terhadap Agency Cost (Studi pada Perusahaan di BEJ). Jurnal Ilmiah Bidang Manajemen dan Akuntansi.13 (2). 194-213.

Bapepam. 2006. Studi Penerapan PrinsipPrinsip OECD 2004 dalam Peraturan Bapepam mengenai Corporate Governance.

Core, JE. 2001. A Review of the Empirical Disclosure Literature: Discussion. Journal of Accounting and Economics, 31. 441-456.

Cowen, S., LD. Ferreri dan LD. Parker. 1987. The Impact of Corporate Characteristics on Social Responsibility Disclosure: A Typology and FrequencyBased Analysis. Accounting, Organization and Society, 12 (2). 111-122.

Fitriani. 2001. Signifikasi Perbedaan Tingkat Kelengkapan Pengungkapan Wajib Dan Sukarela Pada Laporan Keuangan Perusahaan Publik Yang Terdaftar Di Bursa Efek Jakarta. Makalah Simposium Nasional Akuntansi IV, Bandung. : Universitas Padjajaran dan Ikatan Akuntan Indonesia.133-154.
Gujarati, D. 2000. Basic Econometrics. Forth Edition, McGraw-Hill.

Hartono, J. 2003. Teori Portofolio dan Analisis Investasi. Edisi III. Yogyakarta: BPFE.

Hadi, N. 2011. Corporate Social Responsibility. Yogyakarta: Graha Ilmu

Haniffa, RM. dan TE. Cooke. 2002. Culture, corporate governance and disclosure in Malaysian corporations. Abacus, 38 (3).

Haniffa, RM. dan TE. Cooke. 2005. The Impact of Culture and Governance on Corporate Social Reporting. Journal of Accounting and Public Policy 24. 391430.

Healy, PM. dan KG. Palepu. 2001. Information asymmetry, corproate disclosure, and the capital markets: A review of the empirical disclosure literature. Journal of Accounting and Economics, 31. 405440.

Hartono, J. 2003. Teori Portofolio dan Analisis Investasi. Edisi III. Yogyakarta: BPFE.

Jensen, MC. dan GM. Meckling. 1976. The Agency Theory Of The Firm: Managerial Behavior, Agency Cost And Ownership Structure. Journal of Financial Economics 3. 305-360.

Junaedi, D. 2005. Dampak Tingkat Pengungkapan Informasi Perusahaan terhadap Volume Perdagangan dan Return Saham: Penelitian Empiris terhadap Perusahaan-Perusahaan yang Tercatat di Bursa Efek Jakarta. Jurnal Akuntansi dan Keuangan Indonesia, 2 (2). 1-28.

Kasmadi dan D. Susanto. 2006. Analisis Faktor-Faktor yang Mempengaruhi Luas Pengungkapan Sukarela dalam Laporan Tahunan PerusahaanPerusahaan di Indonesia. STIE YKPN.

Kelly, GJ. 1981. Australian Social Responsibility Disclosure: Some Insights Into Contemporary Measurement. Accounting and Finance. 97-107.

Marwata. 2006. Hubungan antara Karakteristik Perusahaan dan Kualitas Ungkapan 
Sukarela dalam Laporan Tahunan Perusahaan Publik di Indonesia. Jurnal ekonomi dan Bisnis, XII (1). 59-66.

McGuire, JB., A. Sundgren dan T. Schneeweis. 1988. Corporate Social Responsibility and Firm Financial Performance. Academy of Management Journal, 31 (4). 854-872.

Meek, R. dan Gray. 1955. Analisis Pengaruh Faktor-Faktor Fundamental Perusahaan Terhadap Kelengkapan Laporan Keuangan.

Matoussi, H. dan R. Chakroun. 2008. "Board Composition, Ownership Structure And Voluntary Disclosure In Annual Reports: Evidence From Tunisia" Laboratoire Interdisciplinaire De Gestion Université-Entreprise (LIGUE).

Muntoro, RK. 2006. Makalah "Mebangun Dewan Komisaris yang Efektif". Universitas Indonesia.

Roberts, RW. 1992. Determinants of Corporate Social Responsibility Disclosures: An Application of Stakeholder Theory. Accounting, Organization and Society. 17 (6). 595-612.

Said, R., Y.Hj Zainuddin dan H. Haron. 2009. "The Relationship between Corporate Social Responsibility and Corporate Governance Characteristics in Malaysian Public Listed Companies". Social Responsibility Journal. 5 (2). 212-226.

Santoso, S. 2000. SPSS Versi 10: Mengolah Data Statistik Secara Profesional. Jakarta: PT Elex Media Komputindo.

Sarwono, J. 2007. Analisis Jalur untuk Riset Bisnis dengan SPSS. Andi: Jakarta.

Sayekti, Y. 2006. Corporate Governance (CG) sebagai Faktor Determinan Pengungkapan Informasi Corporate Social Responsibility (CSR) dalam Annual Report Perusahaan. Tugas Mata Kuliah Seminar in Corporate Finance and Governance, Tidak Dipublikasikan, Program PIA FEUI, Jakarta.

Sayekti, Y. dan LS. Wandabio. 2007. Pengaruh CSR Disclosure terhadap Earning
Response Coefficient. Simposium Nasional Akuntansi X, Universitas Hasanudin, Makassar, 26-28 Juli 2007.

Sembiring, ER. 2003. Kinerja Keuangan, Political Visibility, Ketergantungan Pada Hutang, dan Pengungkapan Tanggungjawab Perusahaan. Simposium Nasional Akuntansi VI, 2003.

Sembiring, ER. 2005. Karakteristik Perusahaan dan Pengungkapan Tanggungjawab Sosial: Study Empiris pada Perusahaan yang Tercatat di Bursa Efek Jakarta. Simposium Nasional Akuntansi VIII, 2005.

Suripto, B. 1999. The Firm Characteristic Effect To Extent Of Voluntary Disclosure In The Annual Report. Simposium Nasional Akuntansi, II: 1-17.

Tarjo. 2008. "Pengaruh Konsentrasi Kepemilikan Institusional dan Leverage terhadap Manajemen Laba, Nilai Pemegang Saham serta Cost of Equity Capital”. Simposium Nasional Akuntansi 11. Pontianak

Trotman, KT. 1979. Social Responsibilities by Australian Companies. The Chartered Accountants in Australia, March. 24-28.

Trotman, KT. dan GW. Bradley. 1981. Associations between Social Responsibility Disclosure and Characteristics of Companies. Accounting, Organizations and Society, 6 (4). 355-362.

Undang-Undang Nomor 25 Tahun 2007 tentang Penanaman Modal

Undang-Undang Nomor 40 Tahun 2007 tentang Perseroan Terbatas

Utama, S. 2007. "Evaluasi infrastruktur pendukung pelaporan Tanggungjawab sosial dan lingkungan di Indonesia". Pidato ilmiah pengukuhan guru besar FEUI. Jakarta

Utomo, MM. 2000. Praktek Pengungkapan Sosial pada Laporan Tahunan Perusahaan di Indonesia (Studi Perbandingan antara Perusahaan-Perusahaan High Profile dan Low Profile). Simposium Nasional Akuntansi 3, 2000. 
Veronica, S. dan S. Utama. 2006. Pengaruh Struktur Kepemilikan, Ukuran Perusahaan, dan Praktek Corporate Governance terhadap Pengelolaan Laba. Jurnal Riset dan Akuntansi, 9 (3). 307-326.

Veronica, S. dan B. Yanivi. 2005. Corporate Governance, Information Asymmetry, and Earning Management. Jurnal Akuntansi dan Keuangan Indonesia, 12 (1). 77-106.
Warta Ekonomi. 2006. Konsep Bisnis Paling Bersinar 2006: Level Adopsinya Kian Tinggi. Warta Ekonomi. Desember 2006. 36-37.

World Business Council for Sustainable Development (WBCSD). 2000. “WBCSD's first report-Corporate social Responsibility". Geneva. 